\title{
Mechanism of Stimulating Ecological Initiatives in Agricultural Development: Application of the US Best Practice in Russia
}

\author{
Natalya V. Medyanik \\ Valeriya V. Bratkova \\ Irina S. Shtapova
}

North-Caucasus Federal University, Russian Federation

Email: natalya-medyanik@yandex.ru

\section{Doi:10.5901/mjss.2015.v6n3s5p133}

\section{Abstract}

\begin{abstract}
This review article reflects on the tools of the mechanism of stimulating ecological initiatives in rural development of the United States, including servitude practices, financial and technical assistance, landscape planning and regional partnership. As part of servitude practices, the eponymous mechanism is implemented to give land and forest a conservation status in order to ensure the long-term productive use of agricultural land currently in production or production of ecosystem goods. Landscape planning in rural areas aimed at emergency and preventive protection of watersheds, as well as the rehabilitation of hydraulic structures. Regional Conservation Partnership Program involves the provision of technical assistance and investment of environmental initiatives on the part of owners and operators of agricultural and nonindustrial private forest lands for conservation of natural resources at the regional level or in the catchment areas. The US best practice of state regulatory measures can be successfully adapted in Russia.
\end{abstract}

Keywords: environmental initiatives, rural development, technical assistance, servitude program, agricultural sector

\section{Introduction}

The incentive mechanism, including the sphere of environmental management, is coupled with the implementation of objectively determined economic interests, the effectiveness of which depend largely on the timely and adequate community awareness of these needs (Medyanik, 2011; Dovgotko and Medvedev, 2013). Proof of this thesis is the successful practice of large-scale environmental initiatives in the agricultural sector in the US, with the national interests being closely linked to the long-term security and productivity of agricultural land. In this context, the American public demonstrates an instructive example to other nations, in formulating their attitude to the land as follows. "A healthy private land is American power. Seven out of every ten acres of land in our country are privately owned. Healthy productive land is the foundation of agricultural prosperity of USA, the cornerstone of environmental quality and the foundation of healthy communities" (Benefits and Products of CTA, 2009, p.4). Implementation of similarly formulated national interests in the rural practice of US is based not only on numerous environmental initiatives that multiply the productivity of land-saving agricultural landscapes and reproducing ecosystem services in rural areas, but also to a wide palette of stimulus measures. The above circumstances formulate scientific and practical interest of an agricultural sector in Russia, defining the purpose of the article - a constructive assessment and systematization of tools on promotion of environmentally oriented agricultural practices in the United States.

\section{Environmental Initiatives in Agricultural Sector}

A key role in the mechanism of stimulation of environmental initiatives in the agricultural sector of the US is played by the Natural Resources Conservation Service (hereinafter NRCS) of the US Department of Agriculture (hereinafter USDA). National Agricultural Statistics Service provides information support and services delivered via an extensive network of service centers at the local level, presented at the official website of the USDA (see http://offices.sc.egov.usda.gov).

The whole wide palette of stimulus measures are implemented as part of the landscape conservation initiatives being aimed at the resolution of ecological and resource problems of national and regional scales on the one hand, and on voluntary participation and local initiative basis on the other. The subjects of these incentives are farmers, ranchers 
and forest areas that implement environmental measures to ensure sustainable agricultural production (Landscape initiatives, 2015).

The US Natural Resources Conservation Service implements stimulation of environmental initiatives in rural development using the following principles:

- Cross-border environmental initiatives - most ecological and resource problems go beyond the farm, county, state, and therefore the most viable solution is transboundary nature of actions;

- Localization efforts and large-scale partnership - local initiative and combination of resources of partners in the program and other enabling instruments determine the success of environmental practices;

- Scientific approach - involves ecological and economic assessment of environmental projects and selection of the most effective option for farmers, which is the basis for the implementation of the system of environmental measures rather than isolated actions;

- Regulatory certainty - the Natural Resources Conservation Service, in cooperation with other regulatory authorities creates environmental initiatives for rural producers;

- Predictable and clear rules that are consistent with the current and potential mechanism of regulation, which ensures sustainable agricultural production.

The program approach is the basis of the incentive mechanism of environmental initiatives in rural development in the USA. The Natural Resources Conservation Service moderates the implementation of an impressive list of programs. Their grouping reflects the tools of incentives for environmental initiatives in key areas of NRCS responsibility (see Table).

Table 1. The list of environmentally oriented rural programs implemented under the patronage of NRCS

\begin{tabular}{ll}
\hline \multicolumn{1}{c}{ Program focus } & \multicolumn{1}{c}{ List of programs } \\
\hline \multirow{2}{*}{ Financial assistance programs } & Environmental Quality Incentives Program, EQIP \\
\cline { 2 - 2 } & Conservation Stewardship Program, CSP \\
\cline { 2 - 2 } Servitude programs & Agricultural Management Assistance, AMA \\
\cline { 2 - 2 } & Agricultural Conservation Easement Program, ACEP \\
\hline Partnership programs & Healthy Forests Reserve Program, HFRP \\
\hline \multirow{2}{*}{ Landscape planning programs } & Watershed and Flood Prevention Operations Program, WFPO \\
\cline { 2 - 2 } & Emergency Watershed Protection Program, EWP \\
\cline { 2 - 2 } & Watershed Rehabilitation Program, WRP \\
\cline { 2 - 2 } Technical assistance programs & Watershed Surveys and Planning Program, WSPP \\
\cline { 2 - 2 } & Conservation Technical Assistance Program, CTA \\
\hline
\end{tabular}

Based on: (NRCS Conservation Programs, 2015)

Thus, the program of landscape planning is focused on emergency and preventive protection of watersheds from damage caused by erosion, flood waters, sediments, as well as the rehabilitation of hydraulic structures, in particular, dams, the lifetime of many of which has approached the 50-year milestone. For example, in 2014 the reconstruction of the 151 dams in 26 states required 262 million USD, thus providing for 47 million Americans with the annual benefits of 2.2 billion US dollars by reducing flood damage and water erosion, recreation services, improving water supply, preserving wildlife habitat (Watershed Rehabilitation, 2015).

As part of the servitude programs the eponymous mechanism is being implemented to give a conservation status to land and forest land in order to ensure the long-term productive use of land in agricultural production or production of ecosystem services, such as natural sanitation of environment and erosion control, preserving wildlife habitat and biodiversity, flood management and replenishment of groundwater resources, providing opportunities for ecologyeducational, scientific, and recreational activities.

In accordance with US law on agriculture (the "Farm Bill") of the $7^{\text {th }}$ of February 2014, the NRCS launched a program of protection of agricultural easements - the "Agricultural Conservation Easement Program" (see Table 1), bringing together pre-existing programs of Wetlands Reserve Program, Grassland Reserve Program and Farm and Ranch Land Protection Program, as well as forest conservation program the Healthy Forests Reserve Program. In the framework of the protection of agricultural easements a mechanism the Agricultural Land Easements and Wetland 
Reserve Easements are being implemented, aimed at the preservation of wetlands and lands used in agriculture and the related benefits.

For example, in the framework of agricultural land easements, NRCS provides financial assistance to eligible partners - Indian tribes, state and local governments, non-governmental organizations that have a program for the protection of farmland and pasture - in the acquisition of agricultural land easements to protect farmland used in agriculture and with certain ecological value. The amount of financial assistance may reach up to $50 \%$ of the market value of agricultural land easement and up to $75 \%$ for meadows of ecological value (Agricultural Conservation Easement Program, 2014).

Land, which can be extended in powers of protection of agricultural easements include cropland, pastures, meadows, farmland and other private non-industrial forestland. Moreover, among the priority-addressed land conservation status provides maximum protection of adjacent land designated for agricultural use. For registration of land as agricultural land easement, NRCS enters into agreements on cooperation with competent partner. Each agricultural land easement must have a plan, designed to ensure long-term sustainability. As part of the mechanism of servitude, NRCS provides technical and financial assistance to private landowners and Indian tribes in the acquisition of an easement on wetlands for the purpose of restoration and conservation, expansion of multiple ecosystem functions while maintaining a comfortable environment for wildlife and enhance the value of wetland land.

There are following types of easements:

- Permanent easements - easements in perpetuity. NRCS pays $100 \%$ of the easement on the acquisition, as well as from 75 to $100 \%$ of the costs for the restoration of land servitude;

- 30-year easements - security easements for 30 years. NRCS covers from 50 to $75 \%$ of the acquisition cost of the easement, and from 50 to $75 \%$ of the costs for restoration;

- Term easements - security easements for a maximum period provided for by the law of the state. NRCS will cover from 50 to $75 \%$ of the easement, and the acquisition of 50 to $75 \%$ of the costs for restoration;

- 30-year contracts - apply only to land owned by Indian tribes with prolongation of provided payments on a 30year period.

It should be noted that in the case of easements on wetlands, NRCS pays all costs associated with their registration, including land surveying, bonitation, and insurance of the property rights (Agricultural Conservation Easement Program, 2014). In addition, the Wetlands Reserve Program provides sharing (i.e. equity) agreements for joint ventures, primarily the financial liabilities to restore, expand the functions and values of wetlands easements without registration. In this case, NRCS pays up to $75 \%$ of the restoration costs (Wetlands Reserve Program, 2015). Thus, for example, for the period from 2009 to 2012 the total amount of financing programs for the conservation of wetlands was more than 2.2 billion US dollars (Environmental Quality Incentives Program, 2014).

Land, eligible for easements on wetlands include cultivated and converted wetlands that can be successfully and profitably recovered. The priority lands include those contributing to the protection and enhancement of habitat for migratory birds and wildlife. These, in line with the Wetlands Reserve Program (2015), may include:

- Wetlands, cultivated under natural conditions;

- Artificially cultivated wetlands;

- Cultivated pasture wetlands;

- Land that can be turned into wetlands as a result of the floods;

- Pasture, grassland or forestland, the hydrology of which have been significantly degraded and can be restored;

- Coastal areas, which are associated with protected wetlands;

- Land adjacent to protected wetlands, which make a significant contribution to wetland services and values;

- Wetlands previously restored within local, regional and federal programs and in need of long-term protection.

Registration of land as an easement wetland, NRCS enters into a contract of sale with private landowners or eligible Indian tribes, which, among other things, provide right to the NRCS to develop and implement a conservation plan for the wetland as servitude. This mechanism provides for the 10-year restoration agreements between the NRCS and landowners, giving a private land of a status of the 30-year or permanent easement for the implementation of measures to restore, protect and enhance forests. To place an easement, applicants must provide proof of ownership of the land or, if the applicant is the lessee, the written consent of the lessor (Healthy Forests Reserve Program, 2015).

During the implementation of contractual conciliation mechanism in US agriculture on the conservation of wetlands a total number of agreements amounted to 14,281 units, covering an area of 2,652,121.2 acres or 1,074,109.1 hectares of land. Thus, the average size of wetlands covered by a single contract is 75.2 hectares. It should be noted that one-third 
(33.8\%) of agreements accounted for five states: New York, Minnesota, Missouri, Louisiana and lowa (Environmental Quality Incentives Program, 2014). While in the state of New York, such agreements are aimed, first of all, to preserve the hydrological regime of the densely populated areas in order to ensure the quality water supply for the urban population, in the rest of the states through which the river of the Mississippi and its tributaries flows, the preservation of wetlands associated with the maintenance of the integrity of the floodplain ecosystems and, as a consequence, performed their nature- and socially important functions.

Stimulation of environmental initiatives in rural development of the US involves partnership mechanism, the implementation of which started in 2014 under the Regional Conservation Partnership Program (Table 1), a key initiator of which is the Natural Resources Conservation Service (NRCS). Similar to the previous programs, such as Agricultural Water Enhancement Program (AWEP), Chesapeake Bay Watershed Program (CBWI), Cooperative Conservation Partnership Initiative (CCPI) and the Great Lakes Basin Program (GLBP), NRCS assumes a joint partnership framework as to provide technical assistance and investment environmental initiatives on the part of owners and operators of agricultural and non-industrial private forest land for the conservation of natural resources and catchment areas at the regional level. Potential partners include agricultural and silvicultural associations, cooperatives of farmers, government (of the state) or local governments, Indian tribes, municipal organizations in the field of water treatment, water supply, irrigated areas, environmental non-governmental organizations and higher education institutions.

Funding under the program is distributed in three categories of projects and in the following proportions (Regional Conservation Partnership Program, 2015):

- $35 \%$ of the funds used to finance projects in Critical Conservation Areas (CCAs): the watershed of the Chesapeake Bay, the Great Lakes region, the basins of the Mississippi, Colorado, DC, area of longifolia pine, delta Gulf of California, the area of the prairie;

- $40 \%$ of the funds used to finance national projects related to water quantity and quality, condition (health) of the soil, air quality, habitat of species at risk;

- $25 \%$ of the money goes to states on priority projects for each of these environmental areas.

Significant block of stimulating environment protection measures implemented as part of financial aid programs. Among such programs the most important positions occupied by the program to stimulate the quality of the environment (Environmental Quality Incentives Program, see Table 1), in which farmers and landowners are provides technical and financial assistance for the planning and implementation of environmental practices on the land agricultural and nonindustrial private forests in previously stipulated contract with NRCS.

The following initiatives are funded in the framework of the program:

- Air quality initiative: introduction of a standard list of environmental abatement of particulate matter and ozonedepleting substances in the "priority" states, the list of which is approved annually by the US Environmental Agency (EPA);

- Energy Initiative for farmers: the development of energy-saving measures on farms through the two types Agricultural Energy Management Plans (AgEMP) for the estate and the surrounding area, also known as energy audits on farms; as well as providing financial and technical assistance in the implementation of the recommended measures;

- Organic initiatives: the financial assistance in the implementation of ecological measures in organic agriculture, as well as assistance to farmers in meeting the requirements of the National Organic Program (NOP);

- National Water Quality Initiative: the assistance to farmers and ranchers in the implementation of systems to reduce runoff of nitrogen, phosphorus, sediment and pathogens from agricultural land in the "priority" watersheds, which in 2014 were 174 small rivers in all US states. In the same year, NRCS allocated nearly 33 million US dollars in financial aid to farmers and ranchers (for reference: in 2012 - 34 million USD, in 2013 28 million USD) (National Water Quality Initiative, 2015);

- A project of the Colorado River Basin salinity: assistance to farmers in the implementation of measures to prevent salinization of the basin of the Colorado River;

- Initiative of tall seasonal tunnels: helping farmers in the design and construction of high-rise seasonal tunnels that enhance crop production in the environmentally sound manner;

- National Landscape Initiative: implemented in the framework of landscape planning programs (see Table 1).

Funding for the program activities carried out by NRCS is implemented via direct financial and technical assistance, and an insignifican part in the form of reimbursablefunds from other sources or transfers to other federal agencies (NRCS Conservation Programs, 2015).

Thus, technical assistance requires scientific expertise, data collection on natural resources, environmental 
technologies and design methods for solving agri-environmental problems for financial support of a project. Its result is the development of the Conservation Activity Plan (CAP) for each potential participant in the program, which must match the CAP list approved annually by the NRCS in the national and state context (Table 2).

Table 2. National list of plans of rural environmental initiatives in the framework of the Environmental Quality Incentive for 2014

\begin{tabular}{|c|c|c|}
\hline code & CAP Plan Name & Description \\
\hline 102 & $\begin{array}{l}\text { Comprehensive Nutrient } \\
\text { Management Plan }\end{array}$ & $\begin{array}{l}\text { conservation plan for the operations associated with the production of agricultural } \\
\text { machinery and animal feed }\end{array}$ \\
\hline 104 & Nutrient Management Plan & management plan for the movement of nutrients in crop and prevent run-off from farmland \\
\hline 106 & Forest Management Plan & management plan aimed at addressing natural resource problems in the agricultural area \\
\hline 108 & Feed Management Plan & $\begin{array}{l}\text { management plan for forage production on the farm, which allows to control the quantity } \\
\text { and quality of nutrients, feed and / or additives in livestock and poultry }\end{array}$ \\
\hline 110 & Grazing Management Plan & plan aimed at addressing natural resource issues in a particular pasture area \\
\hline 112 & Prescribed Burning Plan & plan aimed at addressing natural resource issues at a specific site through the use of fire \\
\hline 114 & Integrated Pest Management & $\begin{array}{l}\text { pest management plan based on the ecosystem approach, providing a combination of } \\
\text { methods - chemical tools of biological control, habitat modification pests and agri cultural } \\
\text { practices, use of resistant cultivars }\end{array}$ \\
\hline 118 & Irrigation Water Management Plan & $\begin{array}{l}\text { plan to control the volume, frequency and speed of water for irrigation, taking into account } \\
\text { soil moisture, transpiration of water by plants, and climate }\end{array}$ \\
\hline 122 & $\begin{array}{l}\text { Agricultural Energy Management } \\
\text { Plan - Headquarters }\end{array}$ & $\begin{array}{l}\text { audit of energy-consuming components and ongoing operations directly on the farm with } \\
\text { the development of energy saving strategy }\end{array}$ \\
\hline 124 & $\begin{array}{l}\text { Agricultural Energy Management } \\
\text { Plan - Landscape }\end{array}$ & $\begin{array}{l}\text { audits and energy-intensive components of current operations on arable land, pasture / hay } \\
\text { fields, forest areas with the recommended strategy for the conservation of energy } \\
\text { resources }\end{array}$ \\
\hline 126 & $\begin{array}{l}\text { Comprehensive Air Quality } \\
\text { Management Plan }\end{array}$ & $\begin{array}{l}\text { plan of assessment practices and strategies of agricultural operations in order to address } \\
\text { the problems related to air quality and atmospheric changes }\end{array}$ \\
\hline 130 & Drainage Water Management Plan & $\begin{array}{l}\text { a plan for monitoring the level of soil water and timely discharge of water from groundwater } \\
\text { or surface agricultural drainage systems for the use of groundwater and crop nutrients }\end{array}$ \\
\hline 134 & $\begin{array}{l}\text { Conservation Plan Supporting } \\
\text { Transition from Irrigation to Dryland } \\
\text { Plan }\end{array}$ & $\begin{array}{l}\text { plan of environmental activities during the transition from irrigated agriculture in arid, } \\
\text { focusing on sustainability crop production and water conservation practices - water } \\
\text { harvesting technologies }\end{array}$ \\
\hline 138 & $\begin{array}{l}\text { Conservation Plan Supporting } \\
\text { Organic Transition }\end{array}$ & $\begin{array}{l}\text { conservation plan of the transition from traditional agricultural and pastoral production } \\
\text { systems to organic }\end{array}$ \\
\hline 142 & Fish and Wildlife Habitat Plan & plan of agricultural activities or environmental practices in the habitat of fish and wildlife \\
\hline 146 & Pollinator Habitat Plan & $\begin{array}{l}\text { plan to preserve a land plot in order to improve, restore and enhance the richness of native } \\
\text { habitats and the pollinators introduced from outside }\end{array}$ \\
\hline 154 & $\begin{array}{l}\text { IPM Herbicide Resistant Weed } \\
\text { Conservation Plan }\end{array}$ & $\begin{array}{l}\text { conservation plan, including the introduction of pest control methods while suppressing } \\
\text { herbicide resistant weeds on arable land }\end{array}$ \\
\hline
\end{tabular}

Source: FY, 2014

Based on these plans and on a contract basis the participants of the program are provided with financial assistance, the total amount of which for the six-year period cannot exceed 300 thous. USD per participant, and 450 thous. USD in the case of special conservation status projects. The advantage enjoyed by persons with an annual (adjusted gross) income of not more than 1 million USD for the 3-year period preceding the year of the conclusion of the original contract commitment, and if two-thirds of the income is obtained by agriculture or forestry.

In addition, the financing of agricultural environmental initiatives is implemented under the grant support provided by NRCS from federal funds. In particulary interesting are Conservation Innovation Grants (CIG). CIG a voluntary program funding on a competitive basis (released via a nationwide and regional contest grants) designed to encourage the development and implementation of innovative approaches and technologies to preserve natural resources and environmental improvement in the agricultural sector. Grantees may not be the federal government or non-governmental organizations, Indian tribes or individuals. For example, for the period from 2004 to 2006, 428 grants were awarded with financial security of 101.5 million USD (Conservation Innovation Grants Showcase: Oral and Poster Abstract Compendium, 2011). 
As part of a national component, CIG funding is declared annually by the financial notices that contain priority to financing the agricultural areas of natural resources, a list of innovative approaches and technologies recommended for implementation in environmental practices, criteria and procedure for competitive selection of grant applications. The latter contains a description of innovative environmental technologies and approaches that are sufficiently studied to be successful for the introduction and transfer to the environmental practices of farmers.

Funding is provided through a grant agreement, where the proportion of $50-50 \%$ of the total cost of the project falls on federal funds and other sources. The grantee is responsible for the implementation of technical assistance and the successful completion of the project, NRCS performs technical supervision. In addition to the national grant competition, a number of states provide regional component of $\mathrm{CIG}$, which is eligible to projects that are localized on a limited area (interstate or state, farm or a small pool), and differential amount of grant funds allocated to each state.

Finally, a significant range of stimulating measures for environmental initiatives are implemented within the framework of Conservation Technical Assistance (CTA) program in the form of: a) development and implementation of management plans for natural resources in terms of their preservation, reproduction and rational use of the local communities, watersheds and other local areas; b) development projects in the agricultural and forest areas that meet the regulations of environmental legislation, the requirements of the Indian tribes, as well as to prepare them for participation in large environmental programs; c) collecting and interpreting information about the status of the land, as well as the basis for decisions about their rational use; d) collection, analysis, interpretation, display and dissemination of information on the status and trends of natural resources in agriculture and related forest management practices in order to develop environmental management and economic decisions; e) assessing the impact of security practices and systems for natural resources; f) conducting educational and informational seminars, excursions, covering local environmental initiatives; g) design, layout and evaluation of the specific situation of more than 167 standard methods of protection of land and related resources (Purpose of the CTA Program, 2015).

Such assistance is carried out through State Technical Committees (STC) and Technical Service Providers (TSP). The online register of the latter and an annual fees of the services provided is carried out by NRCS (see TSP Registry, TechReg). State Technical Committees are eligible to:

- provide information and guidance to USDA on the environmental issues;

- test problems of the use of natural resources and the need for programs;

- recommend environmental standard practices and other specifications;

- provide recommendations on the state and national policy programs based on the natural resources;

- review the activities of the local working groups to provide public environmental priorities to be solved at the local level;

- assist NRCS in public outreach, awareness of the target groups, as well as identifying their training needs (State Technical Committees, 2010).

With regard to technical service providers (TSP), they may be individuals or organizations that are certified to carry out technical expertise in the planning and design of various environmental activities. Providers offer technical services on a reimbursable basis, on behalf of Natural Resources Conservation Service (NRCS), which hold an online registry service.

\section{Conclusion}

Incentive mechanism for environmental initiatives in rural development of the US includes a broad palette of stimulus measures implemented under the framework of landscape conservation initiatives, aimed at solving the ecological and resource problems of national and regional scales, and is based on voluntary participation and local initiatives. Incentive mechanism is presented in the programs of financial and technical assistance, spatial planning and partnership, security easements, being more than 40 in total. Environmental initiatives are implemented on the principles of science, localization efforts and broad partnerships, cross-border participation, regulatory certainty and legitimacy in the national format.

The initiatives on sustainable development of agricultural production are characterized by multi-subjective nature, key agents which are the Natural Resources Conservation Service (NRCS), the US Department of Agriculture (USDA), an extensive network of service centers, on the one hand, and farmers, tribes, owners of farmland and forest areas on the other hand. The large-scale environmental initiatives and regulatory actions cover 50 US states, the District of Columbia, Puerto Rico, the Virgin Islands, Guam, Samoa, the Commonwealth of the Northern Mariana Islands, the Federated States of Micronesia, Republic of Palau and the Marshall Islands. They includes a wide palette of stimulus 
measures implemented under the landscape conservation initiatives, aimed at ecological and resource problems of national and regional scales, as well as on voluntary participation and local initiatives.

Mechanism for environmental initiatives is presented the programs of financial and technical assistance, spatial planning and partnership, security easements, more than 40 programs in total, being implemented on the principles of science, localization of efforts, broad partnerships, cross-border environmental initiatives, and legitimacy in the national format.

It should be noted that the review undertaken by the incentive mechanism of environmental initiatives in the agricultural sector are applicable in economic practice of Russian ecological and landscape principles of agriculture. We believe that constructive US experience could be applied in rural areas of the country where environmental systems are substantially transformed by agricultural practices with the need for ecological reconstruction of individual natural objects, as well as the restoration of entire landscapes.

\section{References}

Agricultural Conservation Easement Program (ACEP) (2014). [Online] Available: http://www.nrcs.usda.gov/wps/portal/nrcs/detail/ national/programs/easements/acep/?cid=stelprdb1242695 (February 15, 2015).

Benefits and Products of CTA (2009). [Online] Available: http://www.nrcs.usda.gov/wps/portal/nrcs/detail/va/home/?cid=nrcs143_008364 (February 12, 2015).

Conservation Innovation Grants Showcase: Oral and Poster Abstract Compendium 2007-2011 (2011). Soil and water conservation society, \& NRCS. [Online] Available: http://www.nrcs.usda.gov/Internet/FSE_DOCUMENTS/stelprdb1045308.pdf (February 11, 2015).

Dovgotko, N., \& Medvedev, L. (2013). Stimulation of rational nature management in recreation systems. Stavropol: Publishing house "Tesera".

Environmental Quality Incentives Program (EQIP) (2014). [Online] Available: http://www.nrcs.usda.gov/Internet/NRCS_RCA/reports/ fb08_cp_eqip.html (February 15, 2015).

FY 2014: EQIP Conservation Activity Plan (CAP) (2014). [Online] Available: http://www.nrcs.usda.gov/wps/portal/nrcs/detail/national/ programs/financial/eqip/?cid=stelprdb1193480 (February 10, 2015).

Healthy Forests Reserve Program (2015). [Online] Available: http://www.nrcs.usda.gov/wps/portal//nrcs/main/national/programs/ easements/forests/ (February 15, 2015).

Landscape initiatives (2015). [Online] Available: http://www.nrcs.usda.gov/wps/portal/nrcs/main/national/programs/initiatives (February 19, 2015).

Medyanik, N. (2011). Environmental management in the system of economic interests. Economic journal, 4 (24), 93-102.

National Water Quality Initiative (2015). [Online] Available: http://www.nrcs.usda.gov/wps/portal/nrcs/detail/national/programs/financial/ eqip/?cid=stelprdb1047761 (February 19, 2015).

Natural Resources Conservation Service (2015). [Online] Available: http://www.nrcs.usda.gov/Internet/NRCS_RCA/reports/fb08_cp_ wrp.html (February 12, 2015).

NRCS Conservation Programs (2015). [Online] Available: http://www.nrcs.usda.gov/wps/portal/nrcs/main/national/programs/ (February 15, 2015).

Purpose of the CTA Program (2015). [Online] Available: http://wwww.nrcs.usda.gov/wps/portal//nrcs/detail/national/programs/technical/? cid=nrcs143_008365 (February 12, 2015).

Regional Conservation Partnership Program (2015). [Online] Available: http://www.nrcs.usda.gov/wps/portal/nrcs/main/nationall programs/farmbill/rcpp (February 12, 2015).

State Technical Committees (2010). [Online] Available: http://directives.sc.egov.usda.gov/viewerFS.aspx?hid=27719 (February 11, 2015).

Watershed Rehabilitation (2015). [Online] Available: http://www.nrcs.usda.gov/wps/portal/nrcs/main/national/programs/landscape/wr/ (February 15, 2015).

Wetlands Reserve Program (2015). [Online] Available: http://www.nrcs.usda.gov/wps/portal/nrcs/main/national/programs/easements/ wetlands/ (February 11, 2015). 
